\title{
4. How to design and deliver reform that makes a real difference: what recent history has taught us as a nation
}

\author{
Paul Kelly
}

This chapter is structured with three objectives in mind. First, it describes the current state of Australia's political culture, which prizes expediency and timidity over boldness and reform zeal-highlighting the problems this then raises for much-needed further reform efforts. Second, it identifies the contributing factors that made the previous, post-1983 reform era so successful in Australia, drawing out the lessons from that history. And third, it will examine where we ought to go from here in terms of future policy reforms. Undoubtedly, the most speculative part of the chapter will concern the future solutions, simply because they are the most difficult to discern.

\section{Australia's present political culture: complacency and timidity}

The 2010 federal election was a dramatic testimony to the shift in Australia's political culture towards policy timidity and short-term horizons. The evidence is plentiful, the most dramatic being Kevin Rudd's sudden removal from officethe first time a palace revolt has replaced a first-term Labor Prime Minister. The Australian Labor Party (ALP) now has had four different leaders over the past four federal elections: Kim Beazley in 2001, Mark Latham in 2004, Kevin Rudd in 2007, and Julia Gillard in 2010. Its intolerance towards poor polls has sealed a new intensity in impatience with a predilection not to fix problems, but to shoot leaders.

The Liberal Party itself has had three parliamentary leaders over this term: Brendan Nelson, Malcolm Turnbull and Tony Abbott. In contrast, the 11-yearlong Howard era seems a nostalgic aberration in terms of its leadership stability. Volatility is now the name of the game.

When Rudd defeated John Howard in 2007, you could have managed to get betting odds of 100:1 that the next election would be a Gillard versus Abbott contest. Yet the improbable came to pass. The old norms and working rules of Australian politics have been torn up. It is not clear what the new rules are, or if 'rules' as such is the way to think about things. 
My view is that the historic, post-1983 reform era-marking the Hawke/ Keating and part of the Howard governments - is largely terminated. If support for reform is to be resuscitated, it will take a different form in future. The causes of the reform era's demise were complex, although perhaps inevitable. Let me try to identify them.

A number of structural factors are at work. First, the post-2003 terms-of-trade boom, driven by China and the emergent economies, has engendered a pervasive complacency in Australia. It is often said that reform is driven by crisis, not prosperity. It is also said that the Australian character is relaxed in prosperity, and propelled into action only by crisis. Both points appear to be true.

Post 2003, John Howard and Peter Costello arguably did not grasp the scale of the new national income surge, or how to maximise its dividend. Too much was spent, and not enough was invested in reform, or enhancing a new productivity agenda. The political will to restructure and improve government programs was lost. There was not sufficient commitment to competition policy, reform of federalism, education, and better infrastructure. Costello held out many hopes, yet disappointed too often. The release of the first Intergenerational Report in 2001-02 was the chance for a new reform agenda but it was not properly seized.

Under the Rudd Government, Australia has survived the global financial crisis without a technical recession, assisted in part by its integration with China. This is a great result, but it has a legacy. Australia is now drifting, psychologically divorced from the crisis in the North Atlantic zone. The Australian public is experiencing cost-of-living pressures, but the political leaders feel no compulsion to offer a substantive and forward-looking reform agenda.

Ross Garnaut, in August 2010, was correct in identifying the unbroken 20-yearold Australian growth cycle as inculcating lethargy in our political system. The claim that we survived the global financial crisis through spending a significant amount of money overlooks the bigger picture. We survived because of the overall quality of our public-policy frameworks, the inheritance from our previous reform efforts, and our capacities to adopt a pre-emptive policy agenda. This relates to issues such as our financial institutions and banks avoiding the sub-prime crisis, no overhanging public debt, and the fact that our Treasury and central bank moved very quickly given the crisis, as well as our integration with China.

The second factor that should be highlighted, however, relates to botched reforms in our recent past. There are many examples, but the main ones are Howard's WorkChoices, Rudd's Carbon Pollution Reduction Scheme (CPRS), and Rudd's mining tax. The moral from these exercises is not just how difficult it is to bring reforms to fruition, but that botched reforms have counterproductive consequences. WorkChoices was misconceived. It helped to destroy the Howard 
Government, and turned the public from a more flexible labour market to a more regulated labour market. It is virtually impossible even to discuss this subject in rational terms today in Australia. And it has definitely made the Coalition trigger shy on reforms across the board. Its tragedy is that Howard in his final term had control of both Houses of Parliament. And the reform dividend from this historic opportunity looks meagre in retrospect.

There are many lessons from the climate-change debacle. The single most important one was Labor's decision not to price carbon without the political cover of bipartisanship. This timidity was reflected in Rudd's paralysis after his bill died in the Senate, and again in his April 2010 decision to defer the issue for another three years. While at the end of John Howard's first term he went to an election on an unpopular goods and services tax (GST), at a comparable time in Rudd's first term, he refused to take his emissions trading scheme (ETS) to an election, despite having branded climate change the greatest moral test of the age. This was a failure of conviction.

It has left the climate-change debate in this country in a weakened and fragmented state. Note, however, there is one possible excuse for the Rudd/ Gillard tactical retreat - their claim that if they had proceeded unilaterally, their reform might not have stuck.

On the mining tax, Labor broke every rule in the tax-reform book. It ambushed the industry. It misunderstood the financial impact of its tax on the industry. It shunned consultation, judging it would be advantaged politically by the confrontation that followed. It spectacularly misjudged in a failure of process and politics.

The resource-tax process had none of the industry consultation involved in the Hawke Government's petroleum tax. It could not have been more different from the Hawke/Keating 1985 tax-reform process: a taxation White Paper by the Treasury, released for debate, a taxation summit, significant modifications to the package arising from the summit, and then the final decisions. Ultimately, the mining tax cost Rudd the prime ministership. It also leaves the shadow of doubt hanging over further serious tax reform.

The third factor to inhibit reform today is the triumph of short termism in politics and in policy making driven by the 24-hour media cycle and the focus-group mentality. And this is a profound problem. The dilemma facing democracies today is the contradiction between the need for long-run, 'big picture' policy commitments to address the economy, demographic change, climate change, tax reform and infrastructural needs on the one hand, and on the other, the fact that politicians run almost exclusively according to a 24-hour media agenda. They approach each day as a 24-hour media battle, with a three-year term consisting of a thousand such daily contests. 
Party faith and ideological conviction are in decline. Both major parties need incumbency to bestow patronage upon their power networks and supporters. Because their market research is much the same, they offer small variations on the same theme. Sometimes bipartisanship is desirable, but sometimes it stifles creative debate. In this timid political culture, 'safety first' is the supreme rule. The power of the negative campaign prevails. Both sides know this. Paul Keating's famous 1993 victory off the back of his anti-GST campaign set the standard. Howard's destruction off the back of WorkChoices confirmed it.

In the 2010 campaign, Gillard was not prepared to expose herself to attack from Abbott by promising a carbon price and an ETS. Instead, she said Labor would act only when there was a political consensus; in other words, when the opposition gives her a free pass. Abbott in turn walked away from any industrial-relations liberalisation - the first time in a generation when the Liberal Party has gone to an election campaign without a commitment to industrial-relations reform. The problem is obvious: the power of the negative campaign that the media will play to, and play up, and that will be reinforced by political advertising.

There are other consequences of timidity. One is the perceived need in reforms to operate by the rule 'everybody ought to be a winner'. This is a deeply inhibiting factor. It influenced the Howard Government; it influenced the Rudd Government's generous compensation in its CPRS. It was Howard's failure to honour this rule that brought him undone on WorkChoices.

The modern Labor Party is partly defined by the model of governing devised by state Labor governments, developed during the Howard era, starting with the Carr Government in New South Wales. The features of this model are control of government through the Premier's office and his/her department, a relentless focus on the media message, policy caution, using incumbency to bolster Labor's support network, and the destruction of the opposition as a viable force.

Labor's recent approach stands in contrast with that pursued by Keating and Howard. They were old-fashioned tribal warriors, both fashioned not only in the Sydney of the 1960s, but also by the Treasury. They believed that by the 1980s Australia faced a historic economic challenge and that their main mission - apart from winning office and winning elections - was to address this great challenge.

The current Labor Party is different. Kevin Rudd and Julia Gillard are not products of the economic debates of the 1980s. They came into Parliament only in 1998 and are fashioned by forces that belong to another generation. They reflect the changing nature of the political system and the pressures arising from the culture of short termism. 
Related to this is the growing sophistication of the lobbying process in Canberra, and the influence of special interest groups over the public interest. The special interest group industry is now huge in Canberra. The role of lobbying has expanded enormously in the national capital; in contrast, there is no lobby for the public interest.

One final point should be raised in this section about the obstacles to reform. Technology in the twenty-first century is creating a new sense of individual empowerment. Institutions that once moulded mass loyalties-from the Church to the trade union, and from the Returned Services League to the local newspaper - are all diminished. So it is with political parties. Once they assumed voter loyalty, relying on the habit voter. Now fickle voters have to be won over or purchased. In a more diverse society with multimedia options, each person becomes an empowered focus group. The result is that it is much more difficult to build consensus for policy reform across the community.

\section{Explaining the success of the post-1983 reform era}

Let us examine some of the factors that underpinned the reform endeavour over the past 25 years. Essentially, this involves looking at what happened from the early 1980s onwards. The first point to make is that the Hawke and Keating reform agenda was driven by a sense of urgency. There was a sense in the early 1980s of national stagnation and decline, symbolised by the 1980s recession. Australia's annual average gross domestic product (GDP) growth during the Fraser era was only 2 per cent-disappointing in historical terms and by international comparisons. Unemployment rose to about 9 per cent during the 1980s recession. There was strong sentiment this stagnation had to be addressed.

Second, the era coincided with the arrival of a new government led by a popular Prime Minister, Bob Hawke, who was also astute in policy terms. The Hawke/ Keating Government was remarkably free of Labor dogma, which had ruined the Whitlam Government, and was prepared to look at policy approaches with a fresh eye.

This leads us to the third factor. When the Hawke Government arrived there was a set of ideas waiting for it-ideas that had been developed over time in agencies such as the Treasury, the Reserve Bank, and the Industries Assistance Commission. These ideas had some support in the Federal Parliament, and quite a lot in the policy media. The agenda essentially involved freer trade, smaller government, deregulation of markets, lower tax rates within a fairer tax system, a more flexible labour market, low inflation, an attack on economic rent-seekers, 
and a more market-orientated economy. There is no doubt that the intellectual momentum of 1980s reforms was elite driven; the ideas came from the top down. It took unusual politicians, however, such as Hawke and Keating to sell them to the community.

The fourth point to make is that Hawke and Keating had a formal contract for consensus: the Accord with the trade-union movement. The decade-long Accord represented a choice by the union movement to switch from an industrial to a political strategy, to give priority to an economic reform agenda and growth strategy with the Labor Party. This meant reforms were often negotiated through the Accord - that is, with the unions first thereby creating a basis for consensus, or at least a move towards broad support.

Another element important in these reforms was the commitment to equity. For the Hawke Government, social and economic equity were vital. Equity was integral to the Accord with Labor's own constituency, and as a tactic in selling its economic reforms. But equity was vital in another sense. Equity was part of the reform agenda itself; it was an aim in its own right.

John Howard is right to argue that in the 1980s the Coalition in opposition supported many of Labor's reform directions. In fact, the opposition was usually attacking the Labor government for not going further and faster. Far from complaining that Labor was engaged in 'rip-and-tear' reformism, the Coalition's typical position was that Labor had been too cautious. This approach gave Hawke and Keating great political flexibility and the chance to occupy the middle ground, which they essentially did for a decade.

The final point to make about this period is that the Hawke Governmentnotably Hawke and Keating - was very effective at putting and winning the intellectual and political case for these policies. Unlike today's politicians, they actually argued the merits. They did not engage purely in spin; they did not engage in empty slogans. For a considerable time, Keating as Treasurer carried much of the media behind him and his policies. Above all, Hawke kept winning elections - and that affirmed the reforms. They worked in political terms. There is not much point introducing a new reform and then losing an election, as Howard did in 2007. The fact that Hawke kept winning elections entrenched the reforms in the system.

Even after the debilitating recession of the early 1990s, reformism remained alive. The great gain from the recession was an independent central bank targeting inflation, and a new era of low inflation. Additionally, the Keating Government advanced enterprise bargaining, increased occupational-based superannuation to 9 per cent and introduced national competition policy. 
The Howard Government entrenched new fiscal rules, discharged public debt, granted full central bank independence, completed a major 'goods and services tax' reform, forced through reform on the waterfront, further liberalised the labour market with the support of the Democrats in 1996, made some decisive privatisations, and presided over a system of sound bank supervision and regulation.

The great irony of Kevin Rudd is his failure to live up to the expectations he created in opposition and in government, and to deliver on the mandate he won at the 2007 election. Rudd promised an emissions trading scheme. He pledged to revive the Council of Australian Governments (COAG) and to fix the federation, ending the blame game. He pledged a new era of human-capital investment that he called an 'education revolution'. No prime minister has ever talked so much about productivity. Ruddism was a phenomenon undermined by too many contradictions. It failed to determine its priorities.

\section{Future prospects for reform}

So where do we go from here? First, we need to rekindle our understanding of political leadership - a matter of high reflection for both sides of politics. I believe this is possible because the public is sick of spin and inaction. Today's leaders should reclaim their mission from the apparatchiks, brokers and spin merchants who have been so persuasive. They need to re-engage with reform visions. There is some evidence that as the proportion of swinging voters increases, more adverse judgments will apply to political leaders who seek merely to avoid the real issues or resort to cosmetics.

Second, an encouraging feature of the 2010 election campaign was that both sides followed a stance of fiscal restraint. Indeed, their proposed bottom lines were not very different, with neither jeopardising the return to surplus within three years. The 2010 election saw few of the big-spending commitments that characterised earlier election campaigns. Both sides seem committed to debt reduction once the surplus is achieved.

Third, we should not underestimate the groundwork laid for future policy advances. There is, arguably, recognition in the community of the problems and the challenges - for example, the need for better planning and improved urban infrastructure, the need for more investment, better transparency and higher standards in education, the need to better address environmental protection, climate change and water issues, policies to manage demographics and ageing, and the need to tackle intergenerational poverty and welfare dependency. The public is disposed to action on most of these fronts. This is important because the first step in reform is recognising the status quo is not good enough. 
Fourth, in the policy community there is widespread agreement on what needs to be done in many areas. The former Secretary of Treasury Ken Henry's agenda of the three Ps - population, participation, and productivity - almost a decade ago has been vital in this process. The role of Treasury, the Reserve Bank, and the Productivity Commission in pushing ideas and frameworks for reform is pivotal. It might take five or 10 years before some ideas turn into breakthrough policy. But this is to be expected. The campaign for lower tariffs was waged for 20 years inside the policy community before the breakthrough came. Although the community might perceive that nothing much is happening, the pressure builds up and eventually the dam wall breaks.

The role of independent inquiries of intellectual standing, such as the Henry Tax Review or the Garnaut Report on Climate Change, is another important mechanism. Such reports can shape public-policy debates for years, influencing politicians, media and stakeholders.

The fifth point to make is that much of the current and emerging reform agenda is about overlapping Commonwealth-state responsibilities. Paul Keating recently said our future productivity gains will rest upon state government performance. But how do we fix the federation? How do we provide more incentives for productivity-enhancing state government policies? And how do we get better synergies between the Commonwealth and the states to tackle these overlapping issues?

Given that we are a federation, future reform is not going to succeed without the commitment of the state governments. Commonwealth-state relations have been one of the most difficult areas of our public policy. Traditionally, the solutions have involved transferring powers from the states to the Commonwealth, and letting the Commonwealth fix the problem. But it is unsustainable in the long run to have a strong Commonwealth compensating for weak states. A new model is needed. Fixing the federation requires a tremendous amount of detail, ideas and collaboration. It is true, however, that a considerable part of the national reform agenda still rests with the Commonwealth - for example, tax and welfare reform, retirement and superannuation policy.

We should acknowledge what we have learnt about reform in the past generation, because few countries have done as well as Australia during this time. We have learnt that the reform must be intellectually sound. That means potential solutions must have been debated and canvassed among policy makers and in the policy media. Consultation and dialogue with stakeholders are vital. Consensus is not easily won; sometimes it cannot be achieved. Nobody asks the government to commit political suicide. But substantive reform demands leadership, courage, communication, and a willingness to risk a government for 
what the leader believes is right. Moreover, we cannot do everything at once. Getting the reform priorities right is critical. Hawke did this well; Rudd did it badly. Winning the intellectual and political debate in the media is vital.

Getting the academy reinvolved has a role. Too much academic work is divorced from public policy. We need to get the wheels better attuned between the academy and policy making. The evidence suggests our universities are far too regulated when we need a greater dynamic and more diversity. Universities are bedevilled still by a one-size-fits-all model. The reward system for academics is based on research papers that are often too narrow and too remote from public policy. We need to reconnect better the academy and public policy.

Politicians must understand the limits to politics itself. They should focus on the most urgent problems, postpone those that are less urgent, and take some issues off the agenda. Take the global financial crisis as an illustration. Suddenly faced with a significant deficit instead of a healthy surplus, a rational government would have reprioritised its agenda, and not attempted everything it had previously promised. Instead, Rudd said nothing would change; he would proceed with the same agenda. No business would have done this. Such an approach created such demands on the political system that it could not deliver.

It is vital to keep our economy and political system flexible. Efficient government and effective markets go together. Sound economic policy and a decent society go together. Morality is not a government monopoly; markets also have their own morality. There is no substitute for leadership and leadership cannot be programmed. It is best produced from a wider talent pool than we are currently attracting into politics. 